\title{
PHYSICAL AND BROMATOLOGICAL CHARACTERISTICS OF COWPEA VARIETIES PREFERRED BY Callosobruchus maculatus (COLEOPTERA: BRUCHIDAE) ${ }^{1}$
}

\author{
GLAUCE PORTELA DE OLIVEIRA ${ }^{2 *}$, DRYELLE SIFUENTES PALLAORO ${ }^{2}$, ELISANGELA CLARETE CAMILI ${ }^{3}$, \\ ÂNDREA CARLA DALMOLIN ${ }^{4}$
}

\begin{abstract}
Cowpea is an herbaceous legume susceptible to several insects and diseases; and the beetle Callosobruchus maculatus is the main pest causing direct losses in the production of this crop. The objective of this work was to assess the physical and bromatological characteristics of beans of cowpea varieties (Bico-deOuro, BRS-Novaera, BRS-Guariba and BRS-Tumucumaque) preferred by $C$. maculatus. Adults of $C$. maculatus were obtained from a storage unit of cowpea beans. The physical and bromatological characteristics and attractiveness of cowpea beans to insects were evaluated in laboratory. The preferences for oviposition with no choice and attraction to cowpea beans by $C$. maculatus are not related to the high protein content or physical characteristics of the bean seed coat (thickness and fiber content), since the insects were more attracted to beans of the variety Bico-de-Ouro, which had low crude protein content, the thickest seed coat and high NDF content.
\end{abstract}

Keywords: Vigna unguiculata. Seed coat. Anatomy.

\section{CARACTERÍSTICAS FÍSICAS E BROMATOLÓGICAS NA PREFERÊNCIA DE Callosobruchus maculatus (COLEOPTERA: BRUCHIDAE) A DIFERENTES VARIEDADES DE FEIJÃO-CAUPI}

RESUMO - O feijão-caupi é uma leguminosa, alvo de vários insetos e doenças, sendo a principal praga que causa perdas diretas o caruncho Callosobruchus maculatus. O objetivo deste trabalho foi relacionar as características físicas e bromatológicas das variedades de feijão-caupi Bico de Ouro, BRS Novaera, BRS Guariba e BRS Tumucumaque à preferência do caruncho C. maculatus. Os indivíduos adultos de C. maculatus foram obtidos em unidade armazenadora de sementes de feijão-caupi. Realizou-se em laboratório a caracterização física e bromatológica das sementes e, teste de atratividade dos insetos. A preferência de oviposição e atratividade de $C$. maculatus aos genótipos de feijão-caupi não estão associadas à atratividade por altos teores de proteína ou às características físicas do tegumento, neste caso espessura e teores de fibra, uma vez que os insetos tiveram maior atratividade pela variedade Bico de Ouro, que apresentou teores reduzidos de proteína bruta, maior espessura do tegumento e maiores teores de fibras em relação às demais variedades.

Palavras-chave: Vigna unguiculata. Tegumento. Anatomia.

\footnotetext{
${ }^{*}$ Corresponding author

${ }^{1}$ Received for publication in 11/30/2016; accepted in 05/09/2017.

${ }^{2}$ Graduate Program in Tropical Agriculture. Universidade Federal de Mato Grosso, Cuiabá, MT, Brazil; glauceoli@gmail.com, dryelle_pallaoro@hotmail.com.

${ }^{3}$ Department of Plant Sciences and Plant Protection, Universidade Federal de Mato Grosso, Cuiabá, MT, Brazil; eccamili@hotmail.com.

${ }^{4}$ Department of Biological Sciences, Universidade Estadual de Santa Cruz, Ilhéus, BA, Brazil; andreacarlad@gmail.com.
} 


\section{INTRODUCTION}

Cowpea [Vigna unguiculata (L.) Walp.] is an herbaceous legume component of the human diet in underdeveloped countries. This species is important due to the high protein content of its beans (AKANDE, 2007; FROTA; SOARES; ARÊAS, 2008). The cultivation of cowpea is an essential activity in Brazil from the socioeconomic and nutritional point of view (TEÓFILO et al., 2008). Cowpea crops in the Cerrado biome of the Brazilian Center-West region are mainly intended for international markets, which increased the interest of agribusiness companies of other regions, contributing to open new markets for this crop (FREIRE FILHO et al., 2011).

Cowpea is susceptible to various insects and diseases caused by viruses, fungi and bacteria, and their damages can be found from sowing to the post-harvest (FREIRE FILHO; LIMA; RIBEIRO, 2005). Callosobruchus maculatus (Coleoptera: Bruchidae) is indigenous to Africa and was distributed in tropical and subtropical regions, where this species is considered the main pest of stored cowpea (HAINES, 1989; PEREIRA et al., 2008). Infestation of $C$. maculatus can begin in the field, with females laying eggs on the surfaces of the beans. These insects are able to break the bean seed coat to reach the endosperm, from which they feed (MARSARO JÚNIOR; VILARINHO, 2011).

According to Lale and Makoshi (2000) and Sá et al. (2014), the resistance of some varieties of cowpea to pests and diseases can be attributed to the physical and chemical characteristics of their seed coat and cotyledons.

Resistance of cowpea genotypes may also be related to varied forms of reserve proteins, which are able to interfere in the development of Bruchidae
(MACEDO et al., 1993). Several researches have been conducted in order to identify cowpea genotypes resistant to $C$. maculatus and possible mechanisms of action in them. However, reports on the effect of some of these physical characteristics, especially those related to seed coat, on the oviposition and survival of $C$. maculatus are inconsistent.

The objective of this work was to assess the physical and bromatological characteristics of beans of cowpea varieties (Bico-de-Ouro, BRS-Novaera, BRS-Guariba and BRS-Tumucumaque) preferred by C. maculatus.

\section{MATERIAL AND METHODS}

The analyzes were conducted in the Seed Laboratory and in the Morphology Laboratory of the Federal University of Mato Grosso (UFMT), Cuiabá, State of Mato Grosso, Brazil. Four varieties of cowpea, produced in the 2014 crop season, were evaluated: Bico-de-Ouro, BRS-Novaera, BRS-Guariba and BRS-Tumucumaque. The main differences among these varieties are bean color, seed coat texture and presence of hilum corona.

The variety Bico-de-Ouro has brown beans and smooth seed coat (Figure 1A); BRS-Novaera has reniform beans of white color, large size, slightly wrinkled seed coat and brown hilum ring (FREIRE FILHO et al., 2008) (Figure 1B); BRS-Guariba has slightly reniform beans of white color, medium size, smooth seed coat, brown hilum ring and no hilum corona (FREIRE FILHO et al., 2004) (Figure 1C); BRS-Tumucumaque has slightly reniform beans of white color, medium size, smooth seed coat, brown hilum ring and no hilum corona (CAVALCANTE; FREIRE FILHO, 2009) (Figure 1D).

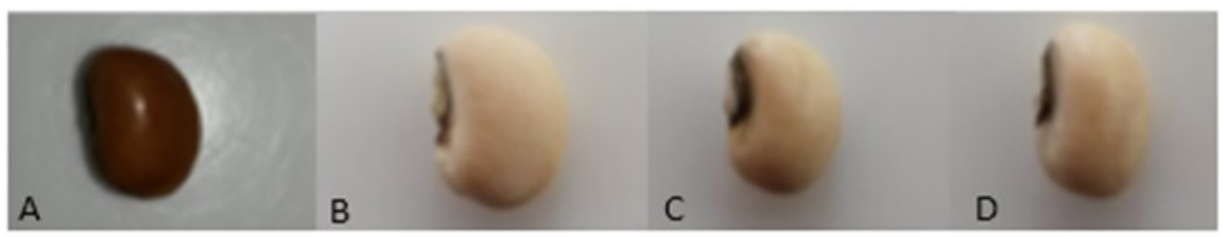

Figure 1. Visual appearance of beans of the varieties Bico-de-Ouro (A), BRS-Novaera (B), BRS-Guariba (C) and BRS-Tumucumaque (D) of cowpea (Vigna unguiculata L. Walp).

The adult individuals of $C$. maculatus used in this work were obtained in a storage unit of cowpea beans and taken to the Seeds Laboratory of the UFMT, where they were multiplied in clear glass containers sealed with a screened lid, containing cowpea beans.

\section{Beans physical and bromatological characteristics}

Seed coat thickness: this characteristic was determined in the Morphology Laboratory of the
Institute of Biosciences of the UFMT, using four replications (beans) of each cowpea variety. The bean seed coats were manually removed, placed in an FAA fix solution $(1: 1: 1 \mathrm{v} / \mathrm{v} / \mathrm{v}$ - formaldehyde, acetic acid, ethanol $70 \%$ ) for 48 hours and then, dehydrated with ethyl alcohol solutions through incremental dilutions (70, 90, 95 and 99\% and absolute alcohol). Subsequently, they were fixed in historesin and sectioned transversely in the region opposite to the hilum, using an ultra-microtome Leica. The histological sectioning was $6-\mu \mathrm{m}$ thick; 
and staining was performed with methylene blue $(0.5 \%)$. Seed coat thickness $(\mu \mathrm{m})$ was measured from photographs using a Leica DM500 optical microscope (Leica Microsystems, Wetzlar, Germany) at $10 \mathrm{x}$, and the program LasCore v3.8 (Leica Microsystems, Wetzlar, Germany).

Crude protein content: three samples of beans $(1 \mathrm{~g})$ of each cowpea variety were ground in a 1-mm mesh sieve. The crude protein content was determined in duplicates by the Semimicro-Kjeldahl method, according to the methodology described by Detmann, Queiroz and Cabral (2012).

Seed coat fiber content: the seed coat was manually separated from the cotyledons to determine the neutral detergent fiber (NDF), acid detergent fiber (ADF) and lignin contents. The seed coats were dried in an oven at $60{ }^{\circ} \mathrm{C}$ to a constant weight and then, refrigerated in a desiccator for approximately two hours. The samples were ground and four replications of the seed coat $(0.5 \mathrm{~g})$ of each variety were used to determine the percentage of NDF, ADF and lignin, as described by Detmann, Valente and Berchielli (2012).

\section{Test of bean attractiveness to insects}

Oviposition preference test: four replications of 16 beans (four beans of each variety), kept in plastic containers in laboratory condition, were simultaneously offered to a couple of $C$. maculatus for oviposition (MARTELETO; LOMÔNACO; KERR, 2009). The eggs were counted at the $10^{\text {th }}$ day after infestation. Firm white eggs were considered as viable and hyaline eggs as non-viable. The oviposition preference was determined by the relative content of eggs in each cowpea variety to the total number of eggs.

Test of bean attractiveness to insects with choice: this test was carried out in a circular arena with plastic containers $(6 \mathrm{~cm}$ in diameter and $5 \mathrm{~cm}$ high) containing $10 \mathrm{~g}$ of beans of the different cowpea varieties in each one. A randomized block experimental design was used, with five replications (arenas). Eighty non-sexed adult insects of $C$. maculatus were released in the central region of each arena (proportion of 20 insects per genotype). These arenas were covered with transparent screened lids and maintained at temperature of $25^{\circ} \mathrm{C}$. The number of individuals in the containers were quantified $24 \mathrm{~h}$ after the insect release.

Data were subjected to analysis of variance and means were compared by the Tukey's test at 5\% of probability. Pearson's simple correlation coefficients were calculated for all variables evaluated.

\section{RESULTS AND DISCUSSION}

The results of the four cowpea varieties evaluated presented differences in bean seed coat characteristics. The beans of the varieties Bico-de-Ouro and BRS-Guariba had greater total seed coat thickness, compared with BRS-Novaera and BRS-Tumucumaque (Table 1).

Table 1. Total thickness of the bean seed coat of four varieties of cowpea (Vigna unguiculata L. Walp).

\begin{tabular}{cc}
\hline Variety & Total thickness $(\mu \mathrm{m})$ \\
\hline Bico-de-Ouro & $112.64( \pm 5.10) \mathrm{a}$ \\
BRS-Novaera & $66.06( \pm 7.93) \mathrm{c}$ \\
BRS-Guariba & $76.59( \pm 9.53) \mathrm{b}$ \\
BRS-Tumucumaque & $69.64( \pm 7.98) \mathrm{c}$ \\
\hline Coefficient of Variation $(\%)$ & 12.57 \\
\hline
\end{tabular}

Means followed by the same letter in the column did not differ by the Tukey's test at $5 \%$ of probability.

The significantly greater bean seed coat thickness of the variety Bico-de-Ouro may be due to the greater thickness of its parenchyma cells (Figure 2A).

Beans of the variety BRS-Novaera had the lowest seed coat thickness and the anatomical cutting of their seed coat showed cuticles with serrated aspect, which is responsible for their typical opaque appearance (Figure 2B).

The results showed differences in the parenchyma cell layer of the seed coats regarding its shape and cellular organization (Figure 2 A-D), confirming the results of Horlings, Gamble and
Shanmugasundaram (1991), who found higher thickness in soybean seed coats in genotypes of black than yellow bean color. According to these authors, beans with thicker seed coat have greater resistance to deterioration in the field.

Regarding the bromatological characteristics, the bean seed coat of the variety BRS-Novaera had the highest crude protein content (11.37\%) (Table 2); BRS-Tumucumaque and Bico-de-Ouro showed significantly higher neutral detergent fiber (NDF) contents. The Bico-de-Ouro also had high contents of acid detergent fiber (FAD) and lignin (LIG), and the lowest hemi-cellulose (HC) contents (Table 2). 

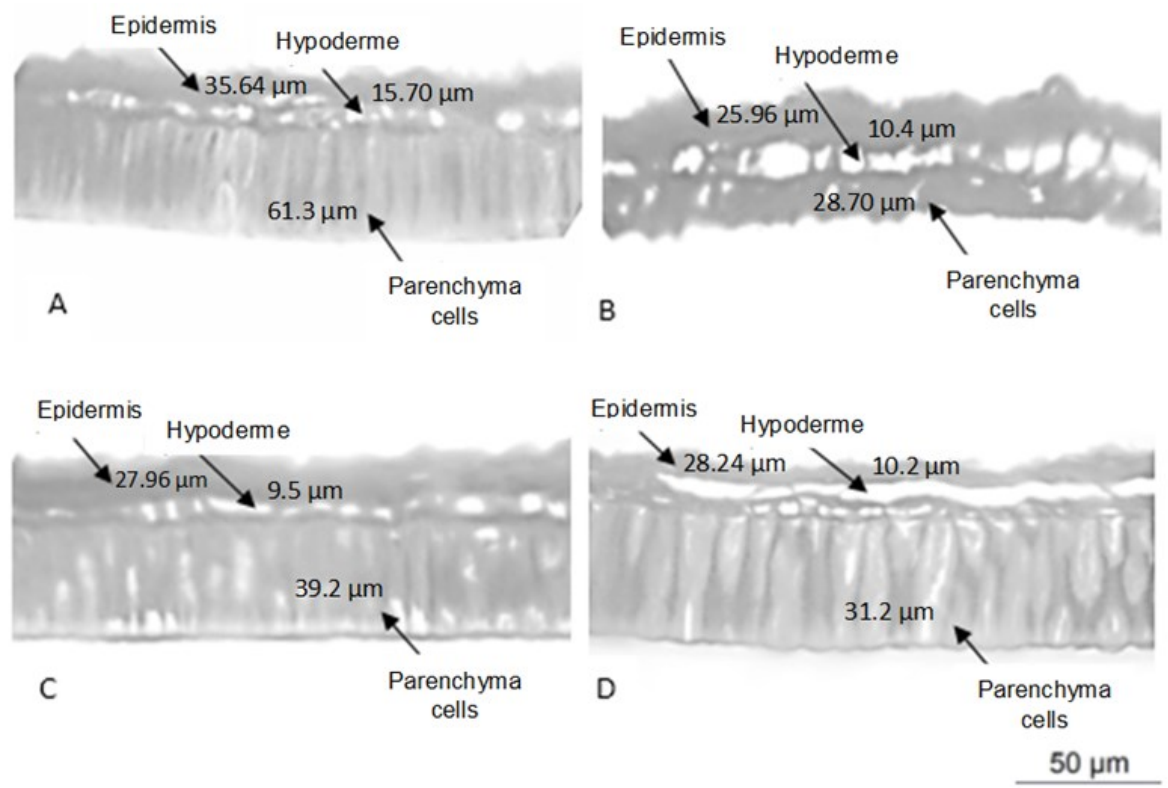

Figure 2. Anatomical cutting of the bean seed coat of the cowpea (Vigna unguiculata L. Walp) varieties Bico-de-Ouro (A), BRS-Novaera (B), BRS-Guariba (C) and BRS-Tumucumaque (D).

Table 2. Crude protein (CP), neutral detergent fiber (NDF), acid detergent fiber (ADF), cellulose (CEL), hemi-cellulose (HC), and lignin (LIG) in the bean seed coat of four varieties of Cowpea (Vigna unguiculata L. Walp).

\begin{tabular}{ccccccc}
\hline Variety & $\begin{array}{c}\text { CP } \\
(\%)\end{array}$ & $\begin{array}{c}\text { NDF } \\
(\%)\end{array}$ & $\begin{array}{c}\text { ADF } \\
(\%)\end{array}$ & $\begin{array}{c}\text { CEL } \\
(\%)\end{array}$ & $\begin{array}{c}\text { HC } \\
(\%)\end{array}$ & $\begin{array}{c}\text { LIG } \\
(\%)\end{array}$ \\
\hline Bico-de-Ouro & $8.11 \mathrm{~b}$ & $63.79 \mathrm{a}$ & $38.5 \mathrm{a}$ & $33.01 \mathrm{a}$ & $25.29 \mathrm{~b}$ & $5.49 \mathrm{a}$ \\
BRS-Novaera & $11.37 \mathrm{a}$ & $57.88 \mathrm{c}$ & $30.53 \mathrm{~b}$ & $27.39 \mathrm{a}$ & $27.35 \mathrm{a}$ & $3.14 \mathrm{~b}$ \\
BRS-Guariba & $7.99 \mathrm{~b}$ & $60.37 \mathrm{~b}$ & $31.37 \mathrm{~b}$ & $29.98 \mathrm{a}$ & $29.01 \mathrm{a}$ & $1.39 \mathrm{c}$ \\
BRS-Tumucumaque & $6.93 \mathrm{c}$ & $64.67 \mathrm{a}$ & $29.61 \mathrm{~b}$ & $28.31 \mathrm{a}$ & $35.06 \mathrm{a}$ & $1.29 \mathrm{c}$ \\
\hline CV (\%) & & 1.19 & 10.35 & 11.47 & 5.73 & 7.72 \\
\hline
\end{tabular}

Means followed by the same letter in the column did not differ by the Tukey's test at $5 \%$ of probability.

Lignin is an antioxidant compound involved in metabolic processes responsible for the food color (DILLARD; GERMAN, 2000). Studies indicate that a greater amount of lignin can be found in seed coats of lineages of dark color seeds (SANTOS et al., 2007; MERTZ et al., 2009; CAVARIANI et al., 2009; OLIVO et al., 2011). This correlation was found in the present work; since the variety Bico-de-Ouro has darker color beans and showed the highest lignin content in its bean seed coat.

Santos et al. (2007) reported that a lignin content in the seed coat greater than $5 \%$ is a good indicator of seed resistance to mechanical damage.
Thus, the results of the present work indicate greater resistance to mechanical damages for the variety Bico-de-Ouro, since its seed coat had $5.49 \%$ of lignin content. The lignification of the seed coat provides seeds with more resistant tissues to mechanical damages and protects its cellulosic wall from attacks by microorganisms (SMÝKAL et al., 2014).

C. maculatus insects were more attracted to the variety Bico-de-Ouro, followed by BRS-Tumucumaque and BRS-Guariba (Table 3). These three varieties had also higher percentages of oviposition by this insect (Table 3 ).

Table 3. Preference of Callosobruchus maculatus for oviposition in beans with no choice and attractiveness of four varieties of cowpea (Vigna unguiculata $\mathrm{L}$. Walp).

\begin{tabular}{ccc}
\hline Variety & Attractiveness (\%) & Oviposition (\%) \\
\hline Bico-de-Ouro & $38 \mathrm{a}$ & $33.2 \mathrm{ab}$ \\
BRS-Novaera & $10 \mathrm{~d}$ & $4.2 \mathrm{c}$ \\
BRS-Guariba & $24 \mathrm{c}$ & $37.4 \mathrm{a}$ \\
BRS-Tumucumaque & $28 \mathrm{~b}$ & $27.6 \mathrm{~b}$ \\
\hline Coefficient of variation (\%) & 6.30 & 12 \\
\hline
\end{tabular}

*Means followed by the same letter in the column did not differ by the Tukey's test at $5 \%$ of probability. 
Regarding the physical and bromatological characteristics, the preference (attractiveness) of $C$. maculatus was positively correlated with seed coat thickness $(\mathrm{r}=0.68)$ and NDF content $(\mathrm{r}=0.88)$, and negative for hemicellulose $(\mathrm{r}=-0.59)$ and crude protein $(\mathrm{r}=-0.81)$ contents. The attractiveness had relatively low correlation with the lignin, cellulose and ADF contents in the different cowpea varieties (Figure 3).
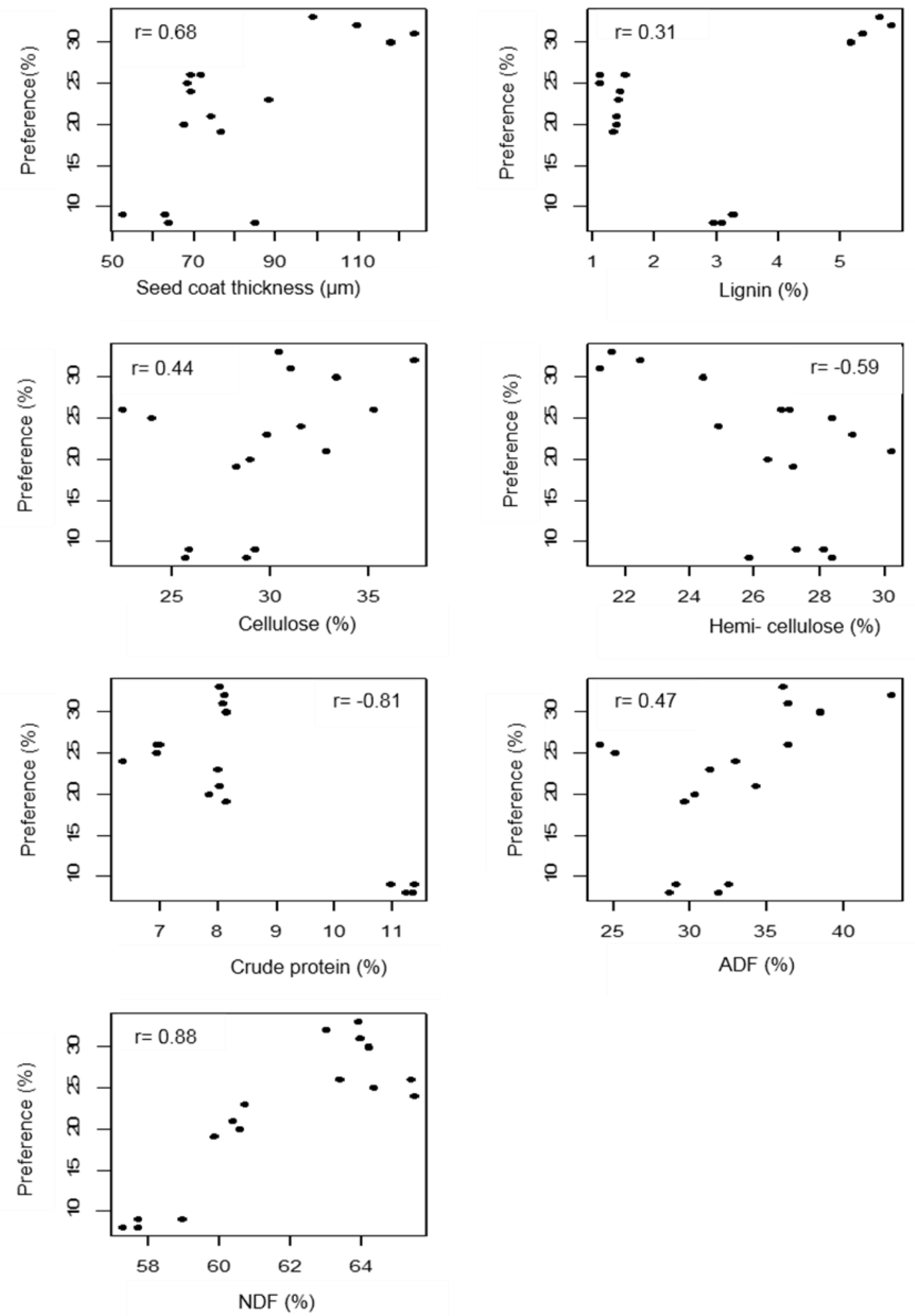

Figure 3. Correlation between seed coat characteristics of four varieties of cowpea (Vigna unguiculata L. Walp) and preferences (attractiveness) of Callosobruchus maculatus. 
The oviposition preference with no choice showed negative correlation with the crude protein content $(\mathrm{r}=-0.81)$, and positive correlation with NDF content $(r=0.60)$ (Figure 4). The correlations with the other variables evaluated were low.

The preferences for oviposition with no choice and attractiveness of cowpea beans to $C$.
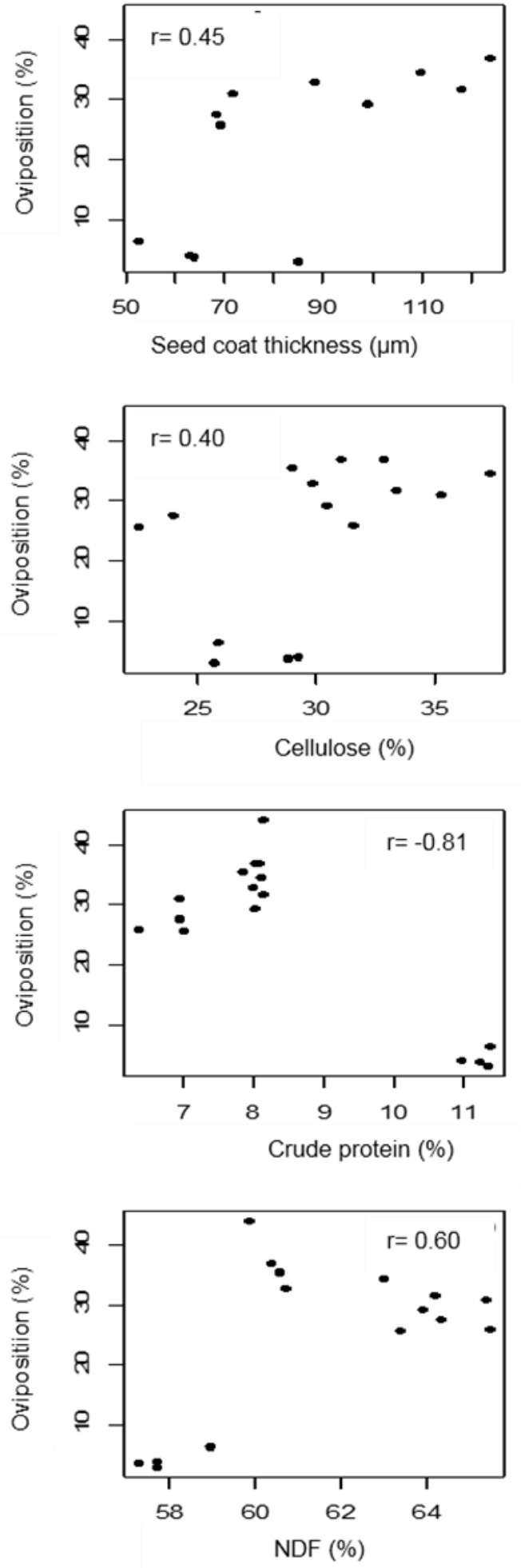

maculatus are not related to their preference for high protein content or physical characteristics of the seed coat (thickness and fiber content), since these insects were more attracted to beans of the variety Bico-de-Ouro, which had low crude protein content, the thickest seed coat and high NDF content.
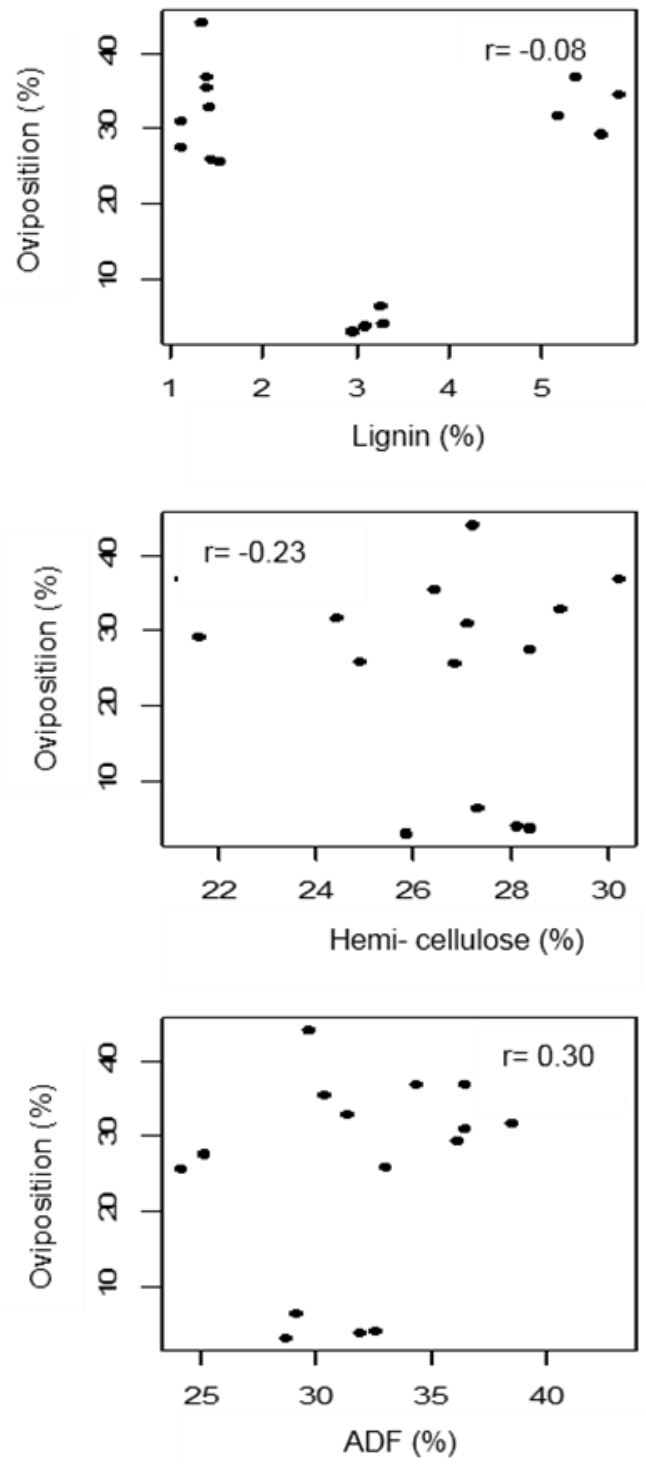

Figure 4. Correlation between seed coat characteristics of four varieties of cowpea (Vigna unguiculata L. Walp) and preference for oviposition with no choice of Callosobruchus maculatus. 


\section{CONCLUSION}

The attractiveness of cowpea beans to Callosobruchus maculatus insects is positively correlated with the neutral detergent fiber content and seed coat thickness, and is negatively correlated with the crude protein and hemicellulose contents of the different varieties evaluated.

\section{ACKNOWLEDGEMENTS}

The authors thank the Brazilian National Institute of Science and Technology in Wetlands (INAU) for providing part of the material for anatomical analysis; and the Coordination for the Improvement of Higher Education Personnel (CAPES) and the Foundation for Research Support of the State of Mato Grosso (FAPEMAT) for granting scholarships to the graduate students of the Graduate Program in Tropical Agriculture.

\section{REFERENCES}

AKANDE, S. R. Genotype by environment interaction for cowpea seed yield and disease reactions in the forest and derived savanna agroecologies of southwest Nigeria. American-Eurasian Journal of Agricultural \& Environmental Science, Deira, v. 2, n. 2, p. 163-168, 2007.

CAVALCANTE, E. S.; FREIRE FILHO, F. R. BRSTumucumaque: cultivar de feijão-caupi para o estado do Amapá. 1. ed. Macapá: Embrapa Amapá, 2009. 2 p. (Folder).

CAVARIANI, C. et al. Velocidade de hidratação em função de características do seed coato de sementes de soja de diferentes cultivares e localidades. Revista brasileira de Sementes, Londrina, v. 31, n. 1, p. 30-39, 2009.

DETMANN, E.; QUEIROZ, A. C.; CABRAL, L. S. Avaliação do nitrogênio total (proteína bruta) pelo método de Kjeldahl. In: DETMANN, E. et al. (Eds.). Métodos para análise de alimentos. Visconde do Rio Branco: Suprema, 2012. v. 1, cap. 4, p. 51-68.

DETMANN, E.; VALENTE, T. N. P.; BERCHIELLI, T. T. Avaliação da fibra insolúvel em detergente neutro e da fibra insolúvel em detergente ácido. In: DETMANN, E. et al. (Eds.). Métodos para análise de alimentos. Visconde do Rio Branco: Suprema, 2012, v. 1, cap. 7, p. 93-111.

DILLARD, C. J, GERMAN, J. B. Phytochemicals: nutraceuticals and human health. Journal of the
Science of Food and Agriculture, Medford, v. 80, n. 1, p. 1744-1756, 2000.

FREIRE FILHO, F. R. et al. BRS-Guariba: nova cultivar de feijão-caupi para a região Meio-Norte. 1. ed. Teresina: Embrapa Meio Norte, 2004. 2 p (Folders).

FREIRE FILHO, F. R. et al. BRS-Novaera: cultivar de feijão-caupi de porte semi-ereto. 1 . ed. Belém: Embrapa Amazônia Oriental, 2008. 4 p. (Comunicado técnico, 215).

FREIRE FILHO, F. R. et al. Feijão-caupi no Brasil: produção, melhoramento genético, avanços e desafios. 1. ed. Teresina, PI: Embrapa Meio-Norte, $2011.84 \mathrm{p}$.

FREIRE FILHO, F. R.; LIMA, J. A. A.; RIBEIRO, V. Q. Feijão-caupi: avanços tecnológicos. 1. ed. Brasília, DF: Embrapa Informação Tecnológica. 2005. 519 p.

FROTA, K. M. G.; SOARES, R. A. M.; ARÊAS, J. A. G. Composição química do feijão caupi (Vigna unguiculata L. Walp), cultivar BRS-Milênio. Ciência e Tecnologia de Alimentos, Campinas, v. 28, n. 2, p. 470-476, 2008.

HAINES, C. P. Observation on Callosobruchus analis (F.). In Indonesia, including a key to storage Callosobruchus spp. (Col.: Bruchidae). Journal of Stored Products Research, Amsterdam, v. 25, n. 1, p. 9-16, 1989.

HORLINGS, G.; GAMBLE, E. E.; SHANMUGASUNDARAM, S. The influence of seed size and seed coat characteristics on seed quality of soybean in the tropics: field weathering. Seed Science and Technology, Londrina, v. 19, n. 3, p. 665-685, 1991.

LALE, N. E. S.; MAKOSHI, M. S. Role of chemical characteristics of the seed coat in the resistance of selected cowpea varieties to Callosobruchus maculatus (F.) (Coleoptera: Bruchidae) in Nigeria. International Journal of Pest Management, Abingdon, v. 46, n. 2, p. 97- 102, 2000.

MACEDO, M. L. R. et al. Vicilin variant and the resistance of cowpea (Vigna unguiculata) seeds to the cowpea weevil (Callosobruchus maculatus). Comparative Physiology and Biochemistry, Amsterdam, v. 105, n. 1, p. 89-94, 1993.

MARSARO JÚNIOR, A. L.; VILARINHO, A. A. Resistência de cultivares de feijão-caupi ao ataque de Callosobruchus maculatus (Coleoptera: Chrysomelidae: Bruchinae) em condições de armazenamento. Revista Acadêmica: Ciências 
Agrárias e Ambientais, Curitiba, v. 9, n. 1, p. 51$55,2011$.

MARTELETO, P. B.; LOMÔNACO, C.; KERR, W. E. Respostas fisiológicas, morfológicas e comportamentais de Zabrotes subfasciatus (Boheman) (Coleoptera: Bruchidae) associadas ao consumo de diferentes variedades de feijão (Phaseolus vulgaris). Neotropical Entomology, Londrina, v. 38, n. 2, p. 178-185, 2009.

MERTZ, L. M. et al. Diferenças estruturais entre seed coatos de sementes de soja com permeabilidade contrastante. Revista brasileira de Sementes, Londrina, v. 31, n. 1, p. 23-29, 2009.

OLIVO, F. et al. Espessura do seed coato e qualidade física e fisiológica de sementes de feijão. Revista Verde, Pombal, v. 6, n. 1, p. 89-88, 2011.

PEREIRA, A. C. R. L. et al. Atividade inseticida de óleos essenciais e fixos sobre Callosobruchus maculatus (Fabr., 1775) (Coleoptera: Bruchidae) em grãos de caupi [Vigna unguiculata (L.) Walp.]. Ciência e Agrotecnologia, Lavras, v. 32, n. 3, p. 717-724, 2008.

SÁ, L. F. et al. Effects of Phaseolus vulgaris (Fabaceae) seed coat on the embryonic and larval development of the cowpea weevil Callosobruchus maculatus (Coleoptera: Bruchidae). Journal of Insect Physiology, Amsterdam, v. 60, n. 1, p. 50-57, 2014.

SANTOS, E. L. et al. Qualidade fisiológica e composição química das sementes de soja com variação na cor do seed coato. Revista brasileira de sementes, Londrina, v. 29, n. 1, p. 20-26, 2007.

SMÝKAL, P. et al. The role of the testa during development and in establishment of dormancy of the legume seed. Frontiers in Plant Science, Lousanne, v. 5, n. 1, p. 1-19, 2014.

TEÓFILO, E. M. et al. Potencial físiológico de sementes de feijão caupi produzidas em duas regiões do Estado do Ceará. Revista Ciência Agronômica, Fortaleza, v. 39, n. 3, p. 443-448, 2008. 